\title{
Foxp3 gene expression in oral lichen planus: A clinicopathological study
}

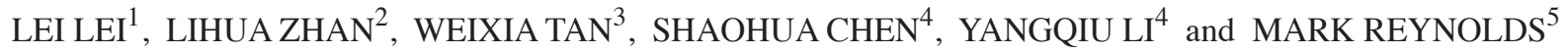 \\ ${ }^{1}$ Department of Stomatology, Medical College of Jinan University, Guangzhou, Guangdong 510632; ${ }^{2}$ Department of \\ Stomatology, First Affiliated Hospital; ${ }^{3}$ DiWang Clinic of Shenzhen Arrail Dental, Shenzhen, Guangdong 518008; \\ ${ }^{4}$ Institute of Hematology, Medical College, Jinan University, Guangzhou, Guangdong 510632, P.R. China; \\ ${ }^{5}$ Department of Periodontics, University of Maryland, School of Dentistry, Baltimore, MA 21201, USA
}

Received April 26, 2013; Accepted November 19, 2013

DOI: $10.3892 / \mathrm{mmr} .2014 .1919$

\begin{abstract}
CD}^{+} \mathrm{CD} 25^{+}$Forkhead-box protein $3\left(\right.$ Foxp $\left.^{+}\right)$ regulatory $\mathrm{T}$ cells are important in oral lichen planus (OLP). The present study aimed to investigate Foxp3 expression in $\mathrm{CD} 4{ }^{+} \mathrm{CD} 25^{+} \mathrm{T}$ cells of peripheral blood mononuclear cells and oral lesions in patients diagnosed with OLP, who were grouped as OLP subtype, duration and relapse. Using quantitative polymerase chain reaction (qPCR), western blotting and immunohistochemistry, Foxp3 expression levels in explants of oral lesions and $\mathrm{CD} 4^{+} \mathrm{CD} 25^{+} \mathrm{T}$ cells from 32 patients with OLP were measured and compared, with 10 healthy subjects as the control group. Foxp3 mRNA expression levels in the explants of oral lesions and circulating $\mathrm{CD} 4{ }^{+} \mathrm{CD} 25^{+} \mathrm{T}$ cells in patients with OLP were significantly higher than those in the control group $(\mathrm{P}<0.05)$. In patients with clinically erosive lesions, Foxp 3 mRNA expression was significantly lower in circulating $\mathrm{CD} 4{ }^{+} \mathrm{CD} 25^{+} \mathrm{T}$ cells and tissue explants compared to patients with reticular lesions $(\mathrm{P}<0.01$ and $\mathrm{P}<0.05$, respectively), and lowest in patients with a history of OLP of $>1$ year or with a history of relapse $(\mathrm{P}<0.05$ and $\mathrm{P}<0.01$, respectively). Foxp3 protein levels in reticular OLP were significantly higher than those in erosive OLP and the control group. The incidence of Foxp3 protein expression in OLP tissues was $36.24 \pm 18.92$ and $10.44 \pm 6.51 \%$ in normal oral mucosa $(\mathrm{P}=0.019)$. Atrophic/erosive OLP lesions showed a higher proportion of Foxp3-expressing cells than that of reticular OLP lesions $(\mathrm{P}<0.05)$. This study indicated that Foxp3 expression in patients with OLP is associated with the severity and duration of the disorder, suggesting altered immune suppression in the development, clinical course and responsiveness to treatment.
\end{abstract}

Correspondence to: Dr Lei Lei, Department of Stomatology, Medical College of Jinan University, 601 Huangpu Dadao, Guangzhou, Guangdong 510632, P.R. China

E-mail: leile230@163.com

Key words: $\mathrm{CD} 4{ }^{+} \mathrm{CD} 25^{+} \mathrm{T}$ cells, Foxp3, immune suppression, oral lichen planus

\section{Introduction}

Oral lichen planus (OLP) is a chronic inflammatory disorder that frequently presents as a white, lacy and reticular pattern on the mucosa, gingiva or lateral border of the tongue (1). The major subtypes of OLP include reticular, erosive, atrophic and popular lesions. Histological examination has shown that lesions are characterized by infiltrating bands of lymphocytes at the epidermal-dermal junction with damage to the basal cells of the epidermis (2). Although the etiology of OLP remains unclear, it appears to be a T cell-mediated autoimmune disorder in which $\mathrm{CD}^{+} \mathrm{T}$ cells induce apoptosis of epithelial cells within the lesion (3). Clones of lymphocytes (the majority of which are $\mathrm{CD}^{+}$) isolated from oral lesions in the lichen planus have been found to have suppressive effects on keratinocytes $(4,5)$. Elevations in proinflammatory cytokine synthesis and membrane receptor expression have been identified in local inflammatory cells and keratinocytes, which then activate multiple signaling networks (6). Previous studies suggested there is a T-helper cell (Th)1/Th2 imbalance in the cell-mediated immune response of $\operatorname{OLP}(7,8)$, which is consistent with the chronic and vacillating inflammatory nature of OLP. Atrophic or erosive lesions may reflect an exacerbated condition and these forms are associated with malignant development (9). Regardless of the central role of $\mathrm{CD} 4{ }^{+} \mathrm{CD} 25^{+}$ regulatory $\mathrm{T}$ cells (Tregs) in the immunological tolerance and suppression of immune activation, limited information on the role of Tregs in OLP is available.

Tregs are $\mathrm{CD} 4^{+} \mathrm{CD} 25^{+} \mathrm{T}$ cells that have a significant role in immune homeostasis and protect against autoimmunity (10). Tregs are anergic via stimulation through the T-cell receptor. Tregs are capable of suppressing the activation of $\mathrm{CD} 4{ }^{+} \mathrm{CD} 25$ and $\mathrm{CD}^{+} \mathrm{T}$ cells through cell contact-dependent mechanisms and cytokine-independent pathways. The aforementioned pathways may involve transforming growth factor- $\beta$ (TGF- $\beta$ ) or interleukin (IL)-10, which is consistent with the immunosuppressive function $(11,12)$. Tregs are also involved in the immune response in a wide spectrum of pathology, such as autoimmune diseases, infectious diseases, allergies, cancer, and organ transplantation (13). The associated molecular markers of Tregs include CD25, Forkhead-box protein 3 (Foxp3), cytotoxic T lymphocyte-associated antigen 4 (CTLA-4) and 
glucocorticoid-induced tumor necrosis factor receptor (GITR). Foxp3 is a member of the highly conserved forkhead/winged helix transcription protein family that controls the development, differentiation, maturation and function maintenance of CD $4{ }^{+} \mathrm{CD} 25^{+}$Tregs $(14,15)$.

Considering the critical role of Foxp3 in the development and function of Tregs, Foxp3 is considered a specific molecular marker of the Treg functional activity $(16,17)$. The aim of the present study was to characterize Foxp3 expression in $\mathrm{CD} 4{ }^{+} \mathrm{CD} 25^{+} \mathrm{T}$ cells from peripheral blood lymphocytes and oral lesions in patients wih OLP (including evaluation of the OLP subtype, duration and relapse).

\section{Materials and methods}

Study subjects. Thirty-two patients with OLP and 10 healthy volunteers were recruited from The First Affiliated Hospital of Jinan University (Guangzhou, China) from 2007 to 2010. Experimental procedures were conducted in accordance with the guidelines of the Medical Ethics committee of the Health Bureau of Guangdong Province of China. Informed consent was obtained from each participant and the study protocol was approved by the Ethics Committee of The First Affiliated Hospital of Jinan University.

Thirty-two patients (females, 23 and males, 9) with an average age of $42.8 \pm 15.4$ years (range, 26-61) were diagnosed with OLP. Patients who had been treated with corticosteroid or immunosuppressive medications in the previous 6 months, and patients with diabetes mellitus and autoimmune diseases (e.g., systemic lupus erythematosus and rheumatoid arthritis) were excluded from this study. Ten gender- and age-matched volunteers served as the healthy controls.

Incisional biopsies were obtained from representative oral lesions. Each biopsy specimen was bisected for histological and molecular assessment. Half of the specimens obtained were fixed in 4\%-buffered formaldehyde and embedded in paraffin for histopathological verification of OLP. The clinical diagnosis of OLP was verified, based on their histopathological features. The histopathological features included lesions characterized by infiltrating bands of lymphocytes at the epidermal-dermal junction with damage to the basal cells of the epidermis. The remaining specimens were minced with surgical blades and immediately immersed in liquid nitrogen, and then stored at $-80^{\circ} \mathrm{C}$ until isolation of the total RNA. Gingival biopsies were obtained from 10 gender- and age-matched subjects immediately after the third molar extraction.

All oral lesions were localized without contact with dental restorations. In terms of OLP subtype, 18 of the 32 patients with OLP presented with reticular lesions, while the remaining patients exhibited erosive or atrophic lesions. According to the duration of disease, based on the self-report of the subjects, patients were divided into three groups: $<6$ months (14 cases); 6-12 months (10 cases); and >12 months (8 cases). Of the 32 patients with OLP, 25 presented with a first diagnosis of OLP and without prior treatment of corticosteroid or immunosuppressive therapy. Seven patients with OLP had previously received corticosteroid or immunosuppressive therapy on $\geq 2$ occasions with clinical relapse. Grouping of the study subjects is shown in Table I.
Preparation of peripheral blood mononuclear cells (PBMCs). Blood samples were collected from all subjects and stored in heparin-containing tubes. PBMCs were isolated immediately using the Ficoll-Hypaque gradient centrifugation technique to further separate $\mathrm{CD} 4^{+} \mathrm{CD} 25^{+} \mathrm{T}$ cells.

$C D 4^{+} C D 25^{+}$T-cell separation by magnetic beads magnetic cell sorting (MACS). Purified human $\mathrm{CD} 4^{+} \mathrm{CD} 25^{+} \mathrm{T}$ cells were isolated according to the manufacturer's instructions in a two-step procedure. CD4 ${ }^{+} \mathrm{T}$ cells were isolated from PBMCs using positive selection with antibody-coated paramagnetic MultiSort MicroBeads [magnetic-activated cell sorting (MACS); Miltenyi Biotec GmbH, Bergisch Gladbach, Germany]. CD $4{ }^{+} \mathrm{CD} 25^{+} \mathrm{T}$ cells were obtained from the $\mathrm{CD} 4^{+}$ T cells with CD25 MicroBeads (Miltenyi Biotec) by positive selection. The purity of the $\mathrm{CD} 4^{+}$and $\mathrm{CD} 4^{+} \mathrm{CD} 25^{+} \mathrm{T}$ cells was established using flow cytometry of cells stained with antihuman CD4-FITC and anti-human CD25-PE (purity of $>95 \%$ $\mathrm{CD}^{+} \mathrm{T}$ cells and $>90 \% \mathrm{CD} 4^{+} \mathrm{CD} 25^{+} \mathrm{T}$ cells).

Total RNA isolation from $C D 4^{+} C D 25^{+} T$ cells and OLP tissues followed by cDNA synthesis. Total RNA was extracted from $\mathrm{CD} 4{ }^{+} \mathrm{CD} 25^{+} \mathrm{T}$ cells using TRIzol reagent (Invitrogen Life Technologies, Carlsbad, CA, USA), following the manufacturer's instructions. Specimens were homogenized in liquid nitrogen and subjected to total RNA extraction using the Tissue RNA Extraction kit (Takara Biotechnology, Dalian, China) and treated with RNase-free DNase (Ambion ${ }^{\circledR}$; Invitrogen Life Technologies) to remove contaminating genomic DNA. The RNA yield and purity were determined by a spectrophotometer at 260/280 nm. RNA samples were treated with DNase in strict accordance with the manufacturers' instructions (Invitrogen Life Technologies). The RNA quality was monitored using spectrophotometry and electrophoresis. The cDNA was synthesized using the Transcriptor First Strand cDNA Synthesis Kit (Roche Diagnostics Corp., Indianapolis, IN, USA) following the manufacturer's instructions.

$q P C R$. For qPCR, primers for the Foxp3 gene and the reference gene (i.e., $\beta$-actin) were: Foxp3; forward, 5'-ACC CCCTTTCACCTACGC-3' and reverse, 5'-CCTTCTC GCTCTCCACTC-3'; and $\beta$-actin; forward, 5'-CACCAA CTGGGACGACAT-3' and reverse, 5'-ACAGCCTGGA TAGCAACG-3'. The primers were synthesized by Shanghai Yingjun Biotechnology Co., Ltd. (Shanghai, China).

Expression levels of Foxp3 and the reference gene ( $\beta$-actin) were determined by SYBR-Green I real-time PCR. PCR was performed as previously described by Chen et al (18). Correction for inefficiencies in RNA input or reverse transcriptase were made by normalization of the housekeeping gene, $\beta$-actin. The $2\left({ }^{-} \mathrm{CT}\right)$ method was used to compare expression levels of Foxp3 relative to $\beta$-actin (19). Briefly, PCR of $25 \mu \mathrm{l}$ total volume was performed with $\sim 1 \mu \mathrm{l}$ cDNA, $0.5 \mu \mathrm{M}$ of each primer and 2.5X RealMasterMix 11.25 $\mu$ l (Tiangen Biotech Co., Ltd, Beijing, China). After the initial denaturation at $95^{\circ} \mathrm{C}$ for $2 \mathrm{~min}, 45 \mathrm{cycles}$ at $95^{\circ} \mathrm{C}(15 \mathrm{sec}), 60^{\circ} \mathrm{C}(60 \mathrm{sec})$ and $82^{\circ} \mathrm{C}(1 \mathrm{sec})$ were performed for plate reading using MJ Research DNA Engine Opticon 2 PCR cycler (Bio-Rad, Hercules, CA, USA). Homogeneity of products from each reaction was confirmed by a melt-curve analysis. The size and quantity of amplified 
Table I. Grouping of participants in relation to the subtype, duration and relapse of OLP.

\begin{tabular}{|c|c|c|c|c|c|c|c|}
\hline \multirow[b]{2}{*}{ Groups } & \multicolumn{2}{|c|}{ OLP subtype } & \multicolumn{3}{|c|}{ OLP duration } & \multicolumn{2}{|c|}{ OLP relapse } \\
\hline & Erosive OLP & Reticular OLP & $>12$ months & 6-12 months & $<6$ months & Relapse & First diagnosis \\
\hline OLP & 14 & 18 & 8 & 10 & 14 & 7 & 25 \\
\hline Control & 10 & & 10 & & & 10 & \\
\hline
\end{tabular}

OLP, oral lichen planus.

products were confirmed by $2 \%$ agarose gels and visualized by staining gels with ethidium bromide. The Foxp3 mRNA expression levels were calculated as previously described (20).

Western blot analysis of Foxp3 expression. The samples were solubilized in lysis buffer containing $20 \mathrm{mM}$ Tris (pH 7.5), 135 mM NaCl, 2 mM EDTA, 2 mM DTT, 25 mM $\beta$-glycerophosphate, $2 \mathrm{mM}$ sodium pyrophosphate, $10 \%$ glycerol, $1 \%$ Triton X-100, $1 \mathrm{mM}$ sodium orthovanadate, $10 \mathrm{mM} \mathrm{NaF}, 10 \mu \mathrm{g} / \mathrm{ml}$ aprotinin, $10 \mu \mathrm{g} / \mathrm{ml}$ leupeptin and $1 \mathrm{mM}$ phenylmethylsulfonyl fluoride for $30 \mathrm{~min}$. Lysates were centrifuged $(15,000 \times \mathrm{g})$ at $4^{\circ} \mathrm{C}$ for $15 \mathrm{~min}$. Equal concentrations of the soluble proteins were denatured in sodium dodecyl sulfate (SDS), electrophoresed on a $12 \%$ SDS-polyacrylamide gel, transferred to nitrocellulose membranes and probed with antibodies, including rabbit anti-human polyclonal antibodies against human Foxp3, goat anti-rabbit antibodies and mouse anti-human GAPDH antibody (Santa Cruz Biotechnology, Inc., Santa Cruz, CA, USA). GAPDH was used as an internal control to monitor equal protein loading. Western blot bands were observed using the Odyssey infrared imaging system (LI-COR Biosciences, Lincoln, NE, USA). The results represent three independent experiments.

Immunohistochemical evaluation of Foxp3 expression. For the immunohistochemical procedure, sections were pre-incubated overnight in Tris-EGTA buffer $(0.05 \mathrm{M}$ Tris and $2.5 \mathrm{mM}$ EGTA) at $60^{\circ} \mathrm{C}$ followed by $1.5 \% \mathrm{H}_{2} \mathrm{O}_{2}$ in Tris-buffered saline (TBS)/Nonidet (TBS; 0.05 M Tris, $\mathrm{pH} 7.4,0.15 \mathrm{M} \mathrm{NaCl}$; with $0.01 \%$ Nonidet P-40) (Sigma-Aldrich, Missouri, MO, USA) for $15 \mathrm{~min}$ at room temperature $\left(20^{\circ} \mathrm{C}\right)$ to extinguish endogenous peroxidase. Subsequently, sections were incubated in $10 \%$ goat serum (In Vitro A/S, Fredensborg, Denmark; code 04009-1B) for $30 \mathrm{~min}$ at room temperature in order to block non-specific binding. Sections were then incubated with antibodies, including rabbit anti-human polyclonal antibodies against human Foxp3. Sections were always processed and stained simultaneously and under the same laboratory conditions. Foxp3 was mainly expressed in the nucleus. The percentage of staining was estimated by two independent observers, three representative areas were selected and evaluated on high-power fields (magnification, x200). The mean percentage of positive cells was represented by the mean of each slide.

Statistical analysis. Data are expressed as the means \pm standard deviation and subject to nonparametric analysis using the Mann-Whitney and Kruskal Wallis tests (IBM SPSS Statistics;
IBM Corp., Armonk, NY, USA). P<0.05 was considered to indicate a statistically significant difference.

\section{Results}

Comparison of Foxp3 mRNA expression between OLP subtypes. Foxp3 mRNA expression was analyzed using qPCR. Correction for inefficiencies in RNA input or reverse transcriptase was made by normalization of the housekeeping gene ( $\beta$-actin). A melting curve analysis was performed to ensure the specificity of the primers. In circulating $\mathrm{CD} 4{ }^{+} \mathrm{CD} 25^{+}$ T cells, Foxp3 mRNA expression in reticular lesions of OLP was significantly higher than that in the erosive lesions and the healthy control group $(1.59 \pm 0.64$ versus $0.76 \pm 0.21$ and $0.58 \pm 0.41$, respectively) $(\mathrm{P}<0.01)$. Compared with that of the control group, Foxp3 mRNA expression in erosive OLP lesions was significantly higher $(0.76 \pm 0.21$ versus $0.58 \pm 0.41$, respectively; $\mathrm{P}<0.01$ ) (Fig. 1A).

The in situ Foxp3 mRNA expression in reticular OLP lesions was significantly higher than that in erosive OLP lesions and the healthy control group $(18.27 \pm 7.83$ versus $11.41 \pm 5.86$ and 9.63 \pm 3.54 , respectively; $\mathrm{P}<0.05)$. Compared with that of the healthy control group, Foxp3 mRNA expression in erosive OLP lesions was significantly higher $(11.41 \pm 5.86$ versus $9.63 \pm 3.54$, respectively; $\mathrm{P}<0.05$ ) (Fig. 1B).

Comparison of Foxp3 mRNA expression levels between groups of OLP duration. Foxp3 mRNA expression levels in circulating $\mathrm{CD}^{+} \mathrm{CD} 25^{+} \mathrm{T}$ cells from patients with OLP duration of $>6$ months (the $>12$ months group and the 6-12 months group, $0.79 \pm 0.53$ and $1.07 \pm 0.78$, respectively) did not differ significantly from that of the control group $(0.58 \pm 0.41)$. Foxp3 mRNA expression levels in patients with OLP duration of $<6$ months $(1.46 \pm 0.96)$ was significantly higher than that in patients with a duration of $>12$ months and the control group ( $\mathrm{P}<0.01)$ (Fig. 2A).

In patients with OLP for $<6$ months, the in situ Foxp3 mRNA expression level $(21.76 \pm 6.38)$ was significantly higher than that of the patients with OLP for $>12$ months $(11.96 \pm 7.13)$ and the healthy controls $(9.63 \pm 3.54)(\mathrm{P}<0.05)$. The in situ Foxp3 mRNA expression levels in patients with OLP for 6-12 months (18.13 \pm 8.57$)$ failed to present a significant difference as compared to the other groups ( $\mathrm{P}>0.05)$ (Fig. 2B).

Comparison of Foxp3 mRNA expression between OLP relapse groups. In circulating $\mathrm{CD} 4{ }^{+} \mathrm{CD} 25^{+} \mathrm{T}$ cells, Foxp 3 mRNA expression of the first diagnosis group $(1.57 \pm 0.64)$ was significantly higher compared with that of the control 

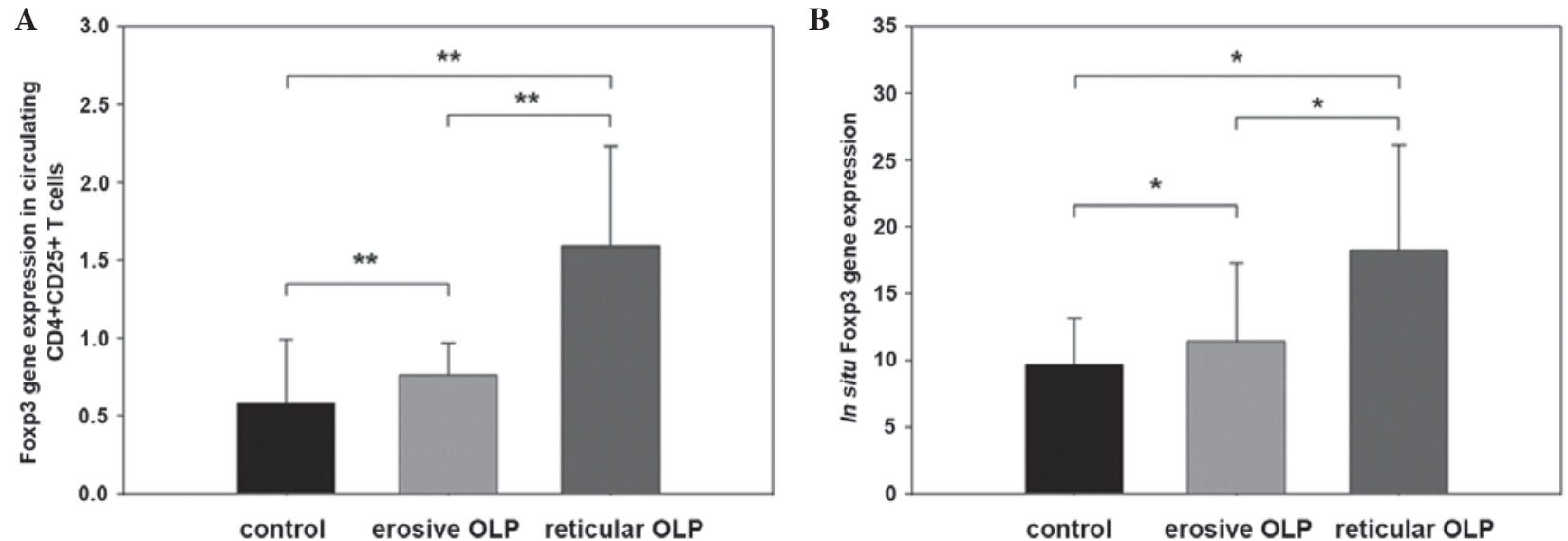

Figure 1. Comparison of Foxp3 gene expression in (A) circulating CD4 ${ }^{+} \mathrm{CD} 25^{+} \mathrm{T}$ cells and (B) in situ, between OLP subtypes $\left({ }^{* * *} \mathrm{P}<0.01\right.$, " $\left.\mathrm{P}<0.05\right)$. OLP, oral lichen planus.
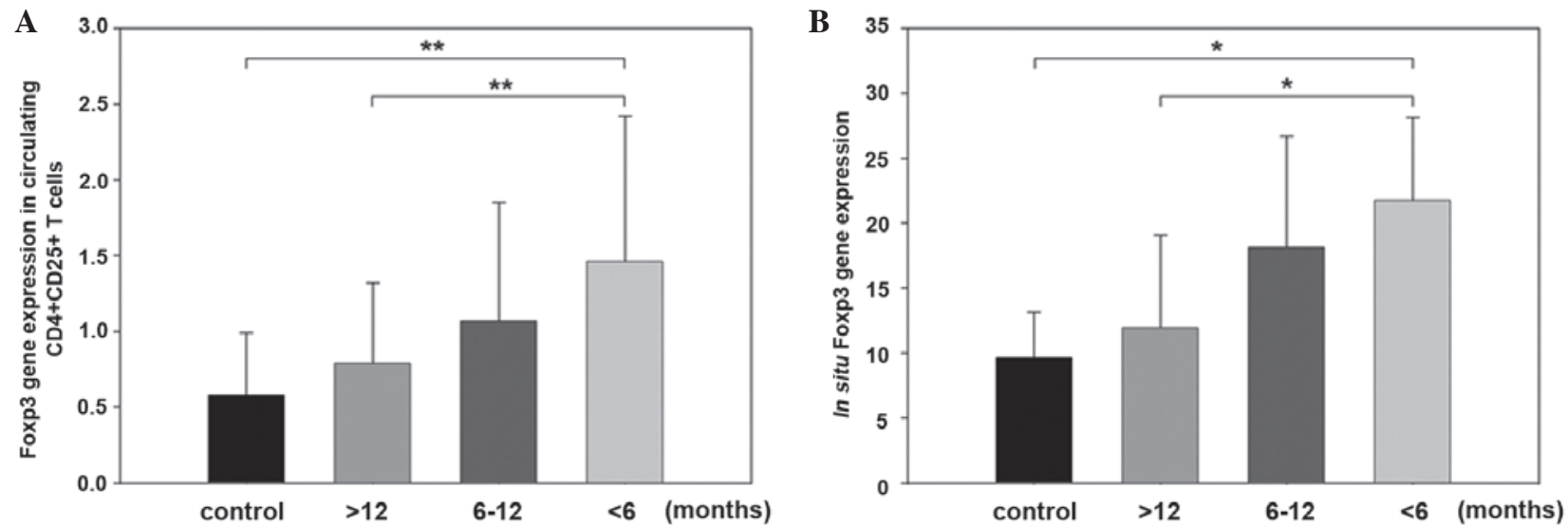

Figure 2. Comparison of Foxp3 gene expression in circulating (A) CD4 ${ }^{+} \mathrm{CD} 25^{+} \mathrm{T}$ cells and (B) in situ, between OLP duration $\left({ }^{* *} \mathrm{P}<0.01,{ }^{*} \mathrm{P}<0.05\right)$. OLP, oral lichen planus.
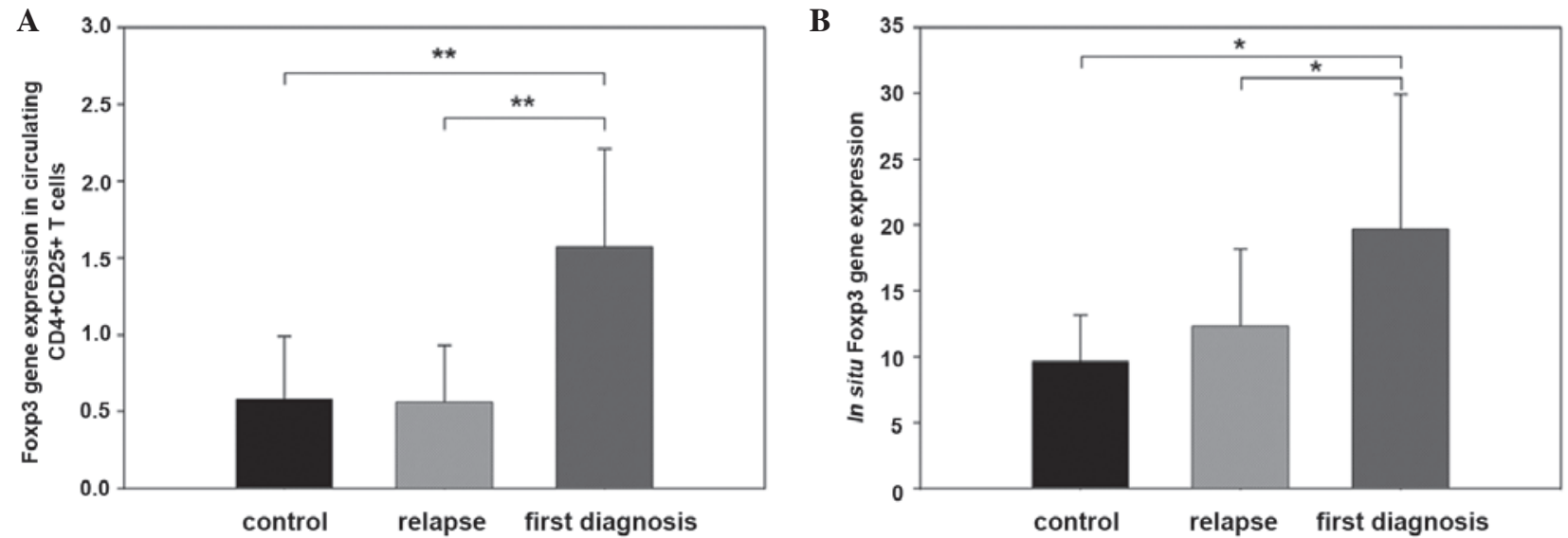

Figure 3. Comparison of Foxp3 gene expression in circulating (A) $\mathrm{CD} 4{ }^{+} \mathrm{CD} 25^{+} \mathrm{T}$ cells and (B) in situ, between OLP relapses $\left({ }^{* *} \mathrm{P}<0.01\right.$, $\left.{ }^{*} \mathrm{P}<0.05\right)$. OLP, oral lichen planus.

and the relapse groups $(0.58 \pm 0.41$ and $0.56 \pm 0.37$, respectively) $(\mathrm{P}<0.01)$. No differences of Foxp3 mRNA expression were found between the control and relapse groups (Fig. 3A).

In situ mRNA expression of Foxp3 was also higher in tissues from patients in the first diagnosis group (19.68 \pm 10.24 ), compared with that of the relapse and control groups
$(12.31 \pm 5.85$ and $9.63 \pm 3.54$, respectively; $\mathrm{P}<0.05)$. No differences of Foxp3 mRNA expression were found between the control group and the relapse group (Fig. 3B).

Foxp3 protein expression was analyzed using western blotting and immunohistochemistry. Foxp3 protein expression 




Figure 4. Western blot analysis of Foxp3 expression. Reticular and erosive OLP lesions and the control are shown in lanes from left to right. OLP, oral lichen planus.

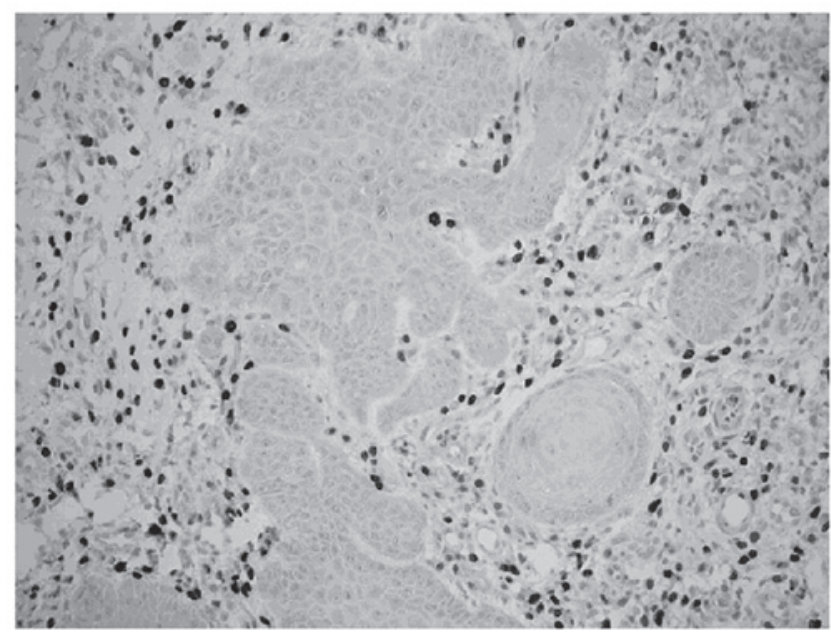

Figure 5. Immunohistochemical staining of Foxp3. Obvious nuclear expression in OLP with streptavidin-peroxidase (magnification, x200).

was analyzed by western blotting. As shown in Fig. 4, Foxp3 protein expression in the reticular OLP lesions was significantly higher than that in the erosive OLP lesions and the healthy control group. In addition, compared with that of the healthy control group, Foxp3 protein expression in the erosive OLP lesions was also high.

Furthermore, as shown in Fig. 5, under a light microscope, the distribution of Foxp3 was mainly observed in the nuclei of lymphocytes, which were sporadically scattered in the lamina propria of local lesions. The incidence of Foxp3 expression in OLP tissues was $36.24 \pm 18.92 \%$ and $10.44 \pm 6.51 \%$ in normal oral mucosa, and there was a significant difference $(\mathrm{P}=0.019)$. Atrophic/erosive OLP lesions showed a higher proportion of Foxp3-expressing cells in the lamina propria of local lesions than that of the reticular OLP $(\mathrm{P}<0.05)$

\section{Discussion}

OLP is typically characterized by a dense, well-defined infiltration of T-lymphocytes in the lamina propria. $\mathrm{CD}^{+}$and $\mathrm{CD}^{+} \mathrm{T}$ cells appear to be predominant in local lesions. These cells have been shown to be cytotoxic $\mathrm{T}$ cells that migrate through the basement membrane in OLP (21). These cells may trigger keratinocyte apoptosis (22) promoted by Th1 cytokines. Previous studies $(23,24)$ have shown that T cells in OLP were resistant to apoptosis resulting in inappropriate immune homeostasis and accumulation of T cells. A number of mechanisms may contribute to the biological basis of OLP (which largely remains unclear), including activation of the inflammatory mediator, nuclear factor- $\kappa \mathrm{B}(25)$, dysfunction of the TGF- $\beta$ signal transduction on $\mathrm{CD}^{+} \mathrm{T}$ cells (26), and $\mathrm{CD}^{+}$and $\mathrm{CD}^{+}{ }^{+} \mathrm{T}$-cell resistance to activationinduced cell death (24), suggesting a dysregulation of local inflammation.

The suppressive function of Tregs is consistent with the hypothesis that the change of Foxp3 expression in T cells may contribute to the pathogenesis of OLP. In the present study, higher levels of Foxp3 mRNA and protein expression in both circulating $\mathrm{CD} 4{ }^{+} \mathrm{CD} 25^{+} \mathrm{T}$ cells and local tissues were found in patients with OLP compared with that of the healthy controls. However, differences in Foxp3 expression were also associated with the clinical form, including reticular versus erosive lesions, and duration and relapse status. Our data suggest that OLP may be associated with the change of Foxp3 expression in $\mathrm{CD} 4{ }^{+} \mathrm{CD} 25^{+}$cells.

Foxp $3^{+} \mathrm{CD} 25^{+} \mathrm{CD} 4{ }^{+}$Tregs are produced in the thymus and are also induced in the periphery from naive $\mathrm{T}$ cells as a functionally mature T-cell subpopulation forming a functionally distinct T-cell subpopulation in the periphery. Tregs are dedicated to the control of immune responses and mediate the tolerance against harmless non-self or self-antigens (27). The differentiation and function of Treg cells require Foxp3 (11,12). A number of autoimmune diseases, such as arthritis, diabetes mellitus, immunodysregulation polyendocrinopathy, enteropathy and X-linked syndrome, may develop spontaneously following elimination of $\mathrm{CD} 4{ }^{+} \mathrm{CD} 25^{+}$ Tregs $(28,29)$.

In the present study, Foxp3 mRNA and protein expression levels in peripheral blood $\mathrm{CD} 4{ }^{+} \mathrm{CD} 25^{+} \mathrm{T}$ cells were higher in patients with OLP than that of the healthy controls. Similar elevations in the expression pattern were observed in local lesions of reticular and erosive forms of OLP, although the expression in the erosive form was lower than that in the reticular form. Foxp3 localization observed in this study supported the findings of Tao et al (30), who identified a higher Foxp3 expression and frequency of Foxp $3^{+}$Tregs in the reticular OLP lesions than that in the erosive OLP lesions. A potential interpretation for the enrichment of Foxp $3^{+}$Tregs in patients with OLP was that Tregs differentially traffic to the oral mucosa in response to chemokines, which is possibly elaborated by keratinocytes. Recent studies $(31,32)$ examining Foxp $3^{+} \mathrm{T}$-cell function in chronic inflammatory conditions, including systemic lupus erythematosus and rheumatoid arthritis, have shown that the Foxp $3^{+} \mathrm{T}$ cells may not have the ability to exert a suppressive function due to the resistance from effector cells. Therefore, such inflammatory diseases may become chronic due to the inability of Tregs to control cytokine-activated T-cell function (33). Our findings also supported the possibility that Foxp $3^{+}$Tregs may be dysfunctional in patients with OLP.

Reduced Foxp3 mRNA expression levels were noted in the erosive OLP lesions than those of the reticular OLP lesions, which were similar to the expression levels in the control group, both in the circulating $\mathrm{CD} 44^{+} \mathrm{CD} 25^{+} \mathrm{T}$ cells and in situ. Immunoregulatory and histological differences have been documented between $\mathrm{T}$ cells in reticular and 
atrophic/erosive OLP $(8,34)$. The epithelial cells in the erosive form of OLP showed increased apoptotic cells as compared to the reticular form (35), which is consistent with the more aggressive form of erosive lichen planus. A previous study hypothesized that the erosive form corresponded to a more active and symptomatic stage of the condition, whereas the reticular form corresponded to a quiescent and asymptomatic phase (36). In the present study, the severity of OLP was significantly associated with Foxp3 expression levels; the greater the severity, the lower the Foxp3 expression levels. The latter observation was consistent with the hypothesis that lower Foxp3 expression levels resulted from upregulation of Foxp3-related suppressive mechanisms in the development of the disorder. With increasing disease severity, characterized by the formation and exacerbation of erosive lesions, the abnormally high ratio of activated $\mathrm{T}$ cells to Treg cells may have hampered the functional ability of Tregs. In this situation, $T$ cells incur resistance to apoptosis resulting in inappropriate immune homeostasis and accumulation of $\mathrm{T}$ cells in the tissues. High proinflammatory cytokine levels may negatively affect the activation of Foxp $3^{+}$Tregs cells in local lesions $(37,38)$. In the active inflammatory compartment, overproduction of Th1 proinflammatory cytokines and deficiencies in TGF- $\beta 1(7,39,40)$ signaling cascades may abrogate Treg-mediated suppression (37,41-44). Moreover, the relative activity of these cytokines may determine the level of immunological activity in OLP lesions and the clinical behavior of the disease (7).

The present study also compared Foxp3 expression and duration of disease, providing an insight into the regulation of the inflammatory response. The results suggest that the protracted disease was associated with reduced Foxp3 expression, which may be partially responsible for the maintenance of the inflammatory infiltrate. Therefore, it was possible that the function and number of Tregs may become increasingly impaired with advancing duration of disease, resulting in continued amplification and extension of local inflammation.

Current therapeutic agents for OLP are largely immunosuppressive and improve the management of symptoms, with clinical relapse commonly occurring after discontinuation of treatment. Pathological alterations in the proportion of immune cells, including regulatory cell subsets, may account for phenotypic differences in the observed inflammatory condition. A diminution of Foxp3 Tregs would represent one possible scenario. In the latter, the failure of Tregs to control autoimmune dysregulation may provide important therapeutic targets for the management of OLP. Several studies have shown that a reduction of Foxp3 levels in natural CD $4{ }^{+} \mathrm{CD} 25^{+}$Tregs blocked their suppressive activities $(45,46)$, and were associated with relapse of the disease (47). The balance between Tregs and $\mathrm{T}$ effector cells may determine corresponding levels of inflammation and therefore, may be linked to periods of relapse or remission.

In conclusion, the present study examined elevated Foxp3 expression levels in circulating $\mathrm{CD} 4^{+} \mathrm{CD} 25^{+} \mathrm{T}$ cells and oral lesions in patients with OLP, suggesting altered immune suppression in the development, clinical course and responsiveness to treatment. The observation of lower Foxp3 expression levels in erosive lesions compared with that of the reticular lesions of lichen planus, further suggested that a dysregulation of suppressor mechanisms contributed to the evolution and chronicity of inflammation.

\section{Acknowledgements}

We would like to thank all authors for their contribution. This study was supported by the Nature Science Foundation of Guangdong Province (grant no. 8151063201000065).

\section{References}

1. de Moura Castro Jacques C, Cardozo Pereira AL, Cabral MG, Cardoso AS and Ramos-e-Silva M: Oral lichen planus part I: epidemiology, clinics, etiology, immunopathogeny, and diagnosis. Skinmed 2: 342-347, 2003.

2. Sugerman PB, Savage NW, Walsh LJ, et al: The pathogenesis of oral lichen planus. Crit Rev Oral Biol Med 13: 350-365, 2002.

3. Sugerman PB and Savage NW: Oral lichen planus: causes, diagnosis and management. Aust Dent J 47: 290-297, 2002.

4. Gadenne AS, Strucke R, Dunn D, Wagner M, Bleichner P and Bigby M: T-cell lines derived from lesional skin of lichen planus patients contain a distinctive population of T-cell receptor gamma delta-bearing cells. J Invest Dermatol 103: 347-351, 1994.

5. Sugerman PB, Savage NW and Seymour GJ: Phenotype and suppressor activity of T-lymphocyte clones extracted from lesions of oral lichen planus. Br J Dermatol 131: 319-324, 1994.

6. Roopashree MR, Gondhalekar RV, Shashikanth MC, et al: Pathogenesis of oral lichen planus - a review. J Oral Pathol Med 39: 729-734, 2010.

7. Khan A, Farah CS, Savage NW, et al: Th1 cytokines in oral lichen planus. J Oral Pathol Med 32: 77-83, 2003.

8. Lu R, Zhou G, Du G, Xu X, Yang J and Hu J: Expression of T-bet and GATA-3 in peripheral blood mononuclear cells of patients with oral lichen planus. Arch Oral Biol 56: 499-505, 2011.

9. Pindborg JJ, Reichart PA, Smith CJ, et al: Histological typing of cancer and precancer of the oral mucosa. In: World Health Organization International histological classification of tumours. 2nd edition. Springer 25, Berlin, Germany, pp29-30, 1997.

10. Sakaguchi S, Sakaguchi N, Asano M, Itoh M and Toda M: Immunologic self-tolerance maintained by activated $\mathrm{T}$ cells expressing IL-2 receptor alpha-chains (CD25). Breakdown of a single mechanism of self-tolerance causes various autoimmune diseases. J Immunol 155: 1151-1164, 1995.

11. Josefowicz SZ, Lu LF and Rudensky AY: Regulatory T cells: mechanisms of differentiation and function. Annu Rev Immunol 30: 531-564, 2012.

12. Wing K and Sakaguchi S: Regulatory T cells exert checks and balances on self-tolerance and autoimmunity. Nat Immunol 11: 7-13, 2010.

13. Taams LS, Palmer DB, Akbar AN, Robinson DS, Brown Z and Hawrylowicz CM: Regulatory T cells in human disease and their potential for therapeutic manipulation. Immunology 118: 1-9, 2006.

14. Hori S, Nomura T and Sakaguchi S: Control of regulatory T cell development by the transcription factor Foxp3. Science 299: 1057-1061, 2003.

15. Gavin MA, Rasmussen JP, Fontenot JD, et al: Foxp3-dependent programme of regulatory T-cell differentiation. Nature 445: 771-775, 2007.

16. Yagi H, Takashi Nomura T, Nakamura K, et al: Crucial role of Foxp3 in the development and function of human $\mathrm{CD} 25^{+} \mathrm{CD} 4^{+}$ regulatory T cells. Int Immunol 16: 1643-1656, 2004.

17. Bignone PA and Banham AH: Foxp3+ regulatory T cells as biomarkers in human malignancies. Expert Opin Biol Ther 8: 1897-1920, 2008.

18. Chen S, Yang L, Lu X, et al: Gene expression profiling of CD3gamma, delta, epsilon, and zeta chains in CD4(+) and CD8(+) $\mathrm{T}$ cells from human umbilical cord blood. Hematology 15: 230-235, 2010.

19. Livak KJ and Schmittgen TD: Analysis of relative gene expression data using real-time quantitative PCR and the 2(-Delta Delta C(T)) Method. Methods 25: 402-408, 2001.

20. Livak KJ and Schmittgen TD: Analysis of relative gene expression data using real-time quantitative PCR and the 2(-Delta Delta C(T)) Method. Methods 25: 402-408, 2001. 
21. Zhou XJ, Sugerman PB, Savage NW, Walsh LJ and Seymour GJ: Intra-epithelial $\mathrm{CD} 8^{+} \mathrm{T}$ cells and basement membrane disruption in oral lichen planus. J Oral Pathol Med 31: 23-27, 2002.

22. Sugerman PB, Satterwhite K and Bigby M: Autocytotoxic T-cell clones in lichen planus. Br J Dermatol 142: 449-456, 2000.

23. Bascones-Ilundain C, Gonzalez-Moles MA, Esparza-Gómez G Gil-Montoya JA and Bascones-Martínez A: Importance of apoptotic mechanisms in inflammatory infiltrate of oral lichen planus lesions. Anticancer Res 26: 357-362, 2006.

24. Lei L, Tan WX, Zhou XL and Zheng PE: Expression of Fas and Fas ligand in infiltrating lymphocytes in patients with oral lichen planus. Zhonghua Kou Qiang Yi Xue Za Zhi 45: 219-222, 2010 (In Chinese).

25. Santoro A, Majorana A, Bardellini E, Festa S, Sapelli P and Facchetti F: NF-kappaB expression in oral and cutaneous lichen planus. J Pathol 201: 466-472, 2003.

26. Lei L, Yu M, Gao XY, Zhou XL and Zhan LH: Expression of TGF-beta receptors in CD8+T cells of oral lichen planus.Zhonghua Kou Qiang Yi Xue Za Zhi 43: 99-100, 2008 (In Chinese).

27. Apostolou I, Sarukhan A, Klein L and von Boehmer H: Origin of regulatory $\mathrm{T}$ cells with known specificity for antigen. Nat Immunol 3: 756-763, 2002.

28. Wildin RS, Ramsdell F, Peake J, et al: X-linked neonatal diabetes mellitus, enteropathy and endocrinopathy syndrome is the human equivalent of mouse scurfy. Nat Genet 27: 18-20, 2001.

29. Lourenço EV and La Cava A: Natural regulatory T cells in autoimmunity. Autoimmunity 44: 33-42, 2011.

30. Tao XA, Xia J, Chen XB, et al: Foxp3 T regulatory cells in lesions of oral lichen planus correlated with disease activity. Oral Dis 16: 76-82, 2010.

31. Vargas-Rojas MI, Crispín JC, Richaud-Patin Y and Alcocer-Varela J: Quantitative and qualitative normal regulatory $\mathrm{T}$ cells are not capable of inducing suppression in SLE patients due to T-cell resistance. Lupus 17: 289-294, 2008.

32. Beavis PA, Gregory B, Green P, et al: Resistance to regulatory $\mathrm{T}$ cell-mediated suppression in rheumatoid arthritis can be bypassed by ectopic foxp3 expression in pathogenic synovial T cells. Proc Natl Acad Sci USA 108: 16717-16722, 2011.

33. Buckner JH: Mechanisms of impaired regulation by CD4(+) CD25(+)FOXP3(+) regulatory $\mathrm{T}$ cells in human autoimmune diseases. Nat Rev Immunol 10: 849-859, 2010.

34. Jungell P, Malmström M, Wartiovaara J, Konttinen Y and Sane J: Ultrastructure of oral leukoplakia and lichen planus I. Basal region and inflammatory cells. J Oral Pathol 16: 170-178, 1987.
35. Brant JMC, Vasconcelos AC and Rodrigues LV: Role of apoptosis in erosive and reticular oral lichen planus exhibiting variable epithelial thickness. Braz Dent J 19: 179-185, 2008.

36. Karatsaidis A, Schreurs O, Helgeland K, Axéll T and Schenck K Erythematous and reticular forms of oral lichen planus and ora lichenoid reactions differ in pathological features related to disease activity. J Oral Pathol Med 32: 275-281, 2003.

37. Wan YY and Flavell RA: The roles for cytokines in the generation and maintenance of regulatory $\mathrm{T}$ cells. Immunological Rev 212: $114-130,2006$.

38. van Amelsfort JM, van Roon JA, Noordegraaf M, et al: Proinflammatory mediator-induced reversal of CD4+, CD25+ regulatory $\mathrm{T}$ cell-mediated suppression in rheumatoid arthritis. Arthritis Rheum 56: 732-742, 2007.

39. Simark-Mattsson C, Bergenholtz G, Jontell M, et al: Distribution of interleukin-2, $-4,-10$, tumour necrosis factor-alpha and transforming growth factor-beta mRNAs in oral lichen planus. Arch Oral Biol 44: 499-507, 1999.

40. Prime SS, Pring M, Davies M and Paterson IC: TGF-beta signal transduction in oro-facial health and non-malignant disease (part I). Crit Rev Oral Biol Med 15: 324-336, 2004.

41. Valencia X, Stephens G, Goldbach-Mansky R, Wilson M, Shevach EM and Lipsky PE: TNF downmodulates the function of human CD4+CD25hi T-regulatory cells. Blood 108: 253-261, 2006.

42. O'Sullivan BJ, Thomas HE, Pai S, et al: IL-1 beta breaks tolerance through expansion of CD25+ effector T cells. J Immunol 176: 7278-7287, 2006.

43. Wan S, Xia C and Morel L: IL-6 produced by dendritic cells from lupus-prone mice inhibits $\mathrm{CD} 4^{+} \mathrm{CD} 25^{+} \mathrm{T}$ cell regulatory functions. J Immunol 178: 271-279, 2007.

44. Marie JC, Letterio JJ, Gavin M and Rudensky AY: TGF-beta1 maintains suppressor function and Foxp3 expression in $\mathrm{CD} 4^{+} \mathrm{CD} 25^{+}$regulatory T cells. J Exp Med 201: 1061-1067, 2005.

45. Wan YY and Flavell RA: Regulatory T-cell functions are subverted and converted owing to attenuated Foxp3 expression. Nature 445: 766-770, 2007.

46. Williams LM and Rudensky AY: Maintenance of the Foxp3-dependent developmental program in mature regulatory T cells requires continued expression of Foxp3. Nat Immunol 8 277-284, 2007.

47. Frisullo G, Nociti V, Iorio R, et al: Regulatory T cells fail to suppress CD4T+-bet+ $\mathrm{T}$ cells in relapsing multiple sclerosis patients. Immunology 127: 418-428, 2009. 